\title{
Coprologic survey of endoparasites from Darwin's fox (Pseudalopex fulvipes) in Chiloé, Chile
}

\author{
Muestreo coprológico de endoparásitos del zorro de Darwin \\ (Pseudalopex fulvipes) en Chiloé, Chile \\ JE Jiménez ${ }^{\mathrm{a}, \mathrm{b}}$, C Briceño ${ }^{\mathrm{c}, \mathrm{d}}$, H Alcaíno ${ }^{\mathrm{e}}$, P Vásquez ${ }^{\mathrm{e}}, \mathbf{S}$ Funk $^{\mathrm{f}}$, D González-Acuña $^{\mathrm{g}^{*}}$ \\ ${ }^{a}$ Sub-Antarctic Biocultural Conservation Program, Department of Biology and Department of Philosophy and Religion Studies, \\ University of North Texas, Denton, United States. \\ bParque Etnobotánico Omora, Universidad de Magallanes, Punta Arenas, Chile. \\ 'Primate Immunogenetics and Molecular Ecology Research Group, Biological Anthropology Department, \\ University of Cambridge, United Kingdom. \\ ${ }^{\mathrm{d} W i l d l i f e}$ Conservation Society, Chile. \\ ${ }^{\text {e}}$ Facultad de Ciencias Veterinarias y Pecuarias, Universidad de Chile, Santiago, Chile. \\ ${ }^{\mathrm{f}}$ Durrell Wildlife Conservation Trust, United Kingdom. \\ gDepartamento de Ciencias Pecuarias, Facultad de Ciencias Veterinarias, Universidad de Concepción, Chillán, Chile.
}

\begin{abstract}
RESUMEN
Un total de 189 heces del zorro de Darwin (Pseudalopex fulvipes [Martin, 1837]) en peligro crítico de extinción, de diferentes localidades de la isla de Chiloé en el sur de Chile, se examinaron en busca de huevos de parásitos y oocitos usando la técnica de flotación en azúcar. Los resultados mostraron que el $21,2 \%$ de las muestras fue positivo a nueve helmintos y/o a un protozoo. Los parásitos con la mayor prevalencia fueron nematodos del orden Ascaridida y un cestodo Spirometra. Otros endoparásitos identificados incluyeron Capillaria sp., Toxocara canis, Toxascaris leonina, Filaroides osleri, nematodos ancylostomatidos, Trichuris sp., Taenia sp., e Isospora sp. Las cargas parasitarias fueron mayores durante el invierno y en áreas con más perros domésticos. Todas estas especies y géneros son reportados por primera vez en el zorro de Darwin.
\end{abstract}

Key words: cestode, Darwin's fox, endogenous parasites, nematode, Pseudalopex.

Palabras clave: cestodo, zorro de Darwin, parásitos endógenos, nematodos.

\section{INTRODUCTION}

The Darwin's fox, Pseudalopex fulvipes (Martin 1837) is not only regarded as one of the world's most threatened species of Canidae, but is also one of the rarest canids in the world (Macdonald and Sillero-Zubiri 2004). Its longterm survival is at risk due to its small population size, with only two known populations restricted to southern Chile. The main population, estimated in less than 300 mature individuals, lives in Chiloé Island $\left(10^{\text {th }}\right.$ Region, $42^{\circ} \mathrm{S}, 74^{\circ} \mathrm{W}$ ) where suitable habitat is undergoing dramatic deterioration and changes due to human activities (Jiménez and McMahon 2004, Jiménez 2007). Hence, it is classified by the IUCN as critically endangered ${ }^{1}$. Throughout Chiloé Island the Darwin's fox inhabits several native forest habitats, where it is the largest wild carnivore and the only native canid. It coexists in sympatry with the

\footnotetext{
Accepted: 02.06.2011.

* danigonz@udec.cl

1 Jiménez JE, M Lucherini, AJ Novaro. 2008. Pseudalopex fulvipes. In: IUCN 2009. IUCN Red List of Threatened Species. Version 2009.1. www.iucnredlist.org. Accessed 12 Sep 2010.
}

kod-kod (Oncifelis guigna), hog-nosed skunk (Conepatus chinga), little grison (Galictis cuja), and with unleashed dogs (Canis familiaris), which are common even in remote areas (Jiménez and McMahon 2004).

There are few studies of parasites from wild canids in Chile. Aguilera (2001) found the endoparasites Toxascaris leonina (von Linstow, 1902), Uncinaria stenocephala (Railliet 1884), Taenia sp. and Echinococcus granulosus (Batsch 1786) in South American grey fox or chilla, Pseudalopex griseus (Gray 1837), from Tierra del Fuego, Chile, whereas Donoso et al (2000) described Sarcocystis sp. from the same host. In Santiago, Chile, Alvarez (1960) isolated the endoparasite Linguatula serrata (Frolich, 1789) from a culpeo fox, Pseudalopex culpaeus (Molina 1782). Recently, González-Acuña et al (2007) reported the louse Trichodectes canis (de Geer 1778) from the Darwin's fox. Currently, there are no records of endoparasites from the Darwin's fox.

This study reports endoparasites of Darwin's fox for the first time. We used the parasite assemblage to infer the means of transmission from the fox prey and the ecological conditions that facilitates the transmission of these 
parasites between the fox and other carnivores, including domestic dogs.

\section{MATERIALS AND METHODS}

During 2003 and 2004, 189 faecal samples from this fox were collected in temperate rainforests of Chiloé Island in southern Chile as part of the Darwin's Fox Research and Conservation Project.

Eleven localities were surveyed throughout Chiloé, as follows: low elevation sites by the sea shore (with open sandy and rocky beaches) such as Quilán (UTM in format WGS 1984 18S: 5267737 m Lat. S, 570399 m Long. W, 77 feces), Ahuenco (5337718, 579862, 23 feces), Tablaruca (5251510, 568730, 11 feces); rugged sites with high elevations (up to $300 \mathrm{~m}$ asl) such as Tepuhueico (5264528, 583997, 29 feces) and Lliuco (5347721, 615807,19 feces); sites at intermediate elevations and with rolling hills such as Huillinco (5276148, 581223, 4 feces), Butamanga (5365028, 618645, 1 feces), Aguas Buenas (5341365, 556862, 2 feces), Catiao (5255544, 569685, 5 feces), Incopulli (5230445, 603345, 13 feces), and Chaiguao (5223562, 623551, 5 feces). The vegetation of these sites has been described by Armesto et al (1996) and is dominated by broad-leaved evergreen trees and a few conifer species, fragmented by varying levels of disturbance and human presence. Most tree species produce fruits that are consumed by the foxes.

Fresh faeces (estimated $\leq 3$ days old), collected from the ground and from individuals trapped, were preserved in $10 \%$ formalin acetate and stored at room temperature until they were analysed. Faeces from the Darwin's fox are distinct in size, shape, and color from those of the other sympatric carnivores. Since faeces were collected over large areas and through trapping, it was assumed that most of them came from different foxes, although in some cases faeces may be produced by the same individual. For example, faeces from the Ahuenco, Lliuco, Quilan, and Tepuhueico sites (that produced $78 \%$ of the faeces) came from populations of at least 9, 4, 7, and 7 different Darwin's foxes, respectively, which we captured and radiotracked (Killian 2005, Jiménez 2007, GónzalezAcuña et al 2007). All faecal samples were processed using standard sugar and zinc sulfate centrifugation, concentration, and flotation techniques (MartínezFernández et al 1999). Eggs, oocysts, and larvae were identified by morphological characteristics and linear measurements to the lowest taxonomic level possible. Prevalence was calculated as the ratio of the number of faecal samples infested (i.e. that had at least one egg) to the total number examined. Terminology used follows Bush et al (1997). Voucher eggs have been deposited in the Parasite Collection, Universidad de Chile, Santiago.

\section{RESULTS AND DISCUSSION}

$40(21.2 \%)$ out of the 189 faecal samples examined were positive and contained ten distinguishable endoparasites (table 1). These represented at least a total of five different identified genera (including two nematodes, two cestodes, and one protozoan); another three nematodes were recognized to species (Toxocara canis, T. leonina, Filarioides osleri). All these endoparasites have been found in domestic dogs in Chile (Alcaino and Gorman 1999). Overall, the most prevalent endoparasite was an ascarid nematode and the Spirometra cestode.

Parasite loads were not homogeneous among localities (table 1). Although sample sizes were small, foxes in Huillinco, followed by those in Ahuenco and then Lliuco and Quilán, had the highest prevalence of endoparasites, whereas those from Tablaruca and Tepuhueico had the lowest. These infection rates correlated well with the relative abundance of dogs at these sites rather than to other variables such as the number of people or houses (Briceño et $a l^{2}$ ). Huillinco is a rural locality located by a busy dirt road with many scattered houses and stray dogs. The next most infested three sites, although remote, were visited regularly by people who owned dogs. Lliuco and Quilán received loggers and had some farmers with unleashed dogs. In fact, locals at Lliuco owned many dogs and the sudden mortality of our three foxes under monitoring was suspected to be caused by a viral disease (likely canine distemper virus) transmitted by dogs. It is interesting that foxes at Incopulli, our southernmost locality rendered no parasites, even though several stray dogs roamed at the site.

Prevalence of the ascarid nematode was high in Quilán (11.7\%). This nematode may be T. canis, a common parasite of domestic dogs in Chile as previously reported by Tagle (1966) and Alcaino and Gorman (1999). T. canis has also been recorded in the congeneric culpeo (González-Acuña ${ }^{3}$ ) and chilla foxes (Alarcón 2005) in several Chilean localities.

The nematode Capillaria sp. was represented by only one sample from Ahuenco. There are two species of this genus recorded in dogs from Chile: $C$. aerophila (Creplin 1839) (Boehmwald et al 1971, Torres et al 1974) and $C$. plica (Rudolphi 1819) (Torres 1971). Both T. leonina and F. osleri were also represented in one faeces each, and both came from Tepuhueico. These two parasites have been recorded in domestic dogs (Tagle 1966, Luengo and Arata 1970) and in chillas from the Magallanes Region (Alarcón 2005, Zanini et al 2006).

$U$. stenocephala had a relatively low prevalence $(2.7 \%)$ in the foxes. Alcaino and Huerta (1970) reported U. stenocephala in domestic dogs in Santiago. Hookworm infections can cause diseases of varying severity, from asymptomatic to mild anemia and fatal hemorrhages, depending on the virulence of the parasite species, as

\footnotetext{
Personal communication.
}

Personal communication. 
Table 1. Prevalence of parasite eggs and oocysts found in Darwin's fox (Pseudalopex fulvipes) faeces in seven areas of Chiloé Island, southern Chile. Only localities with infested faeces are shown.

Prevalencia de huevos y oocitos de parásitos encontrados en heces de zorros de Darwin (Pseudalopex fulvipes) en siete localidades de la Isla de Chiloé, sur de Chile (ver Materiales y Métodos). Sólo se muestran las localidades con heces infectadas.

\begin{tabular}{|c|c|c|c|c|c|c|c|c|}
\hline Parasites & $\begin{array}{c}\text { Huillinco } \\
\mathrm{n}=4\end{array}$ & $\begin{array}{c}\text { Ahuenco } \\
\mathrm{n}=23\end{array}$ & $\begin{array}{l}\text { Lliuco } \\
\mathrm{n}=19\end{array}$ & $\begin{array}{l}\text { Quilán } \\
\mathrm{n}=77\end{array}$ & $\begin{array}{c}\text { Catiao } \\
\mathrm{n}=5\end{array}$ & $\begin{array}{c}\text { Tablaruca } \\
\mathrm{n}=11\end{array}$ & $\begin{array}{c}\text { Tериhuеiсо } \\
\mathrm{n}=29\end{array}$ & $\begin{array}{c}\text { Total } \\
\mathrm{n}=189\end{array}$ \\
\hline \multicolumn{9}{|l|}{ Nematoda } \\
\hline Capillaria sp. & & 1 & & & & & & 1 \\
\hline Ascarideo & 1 & & 1 & 9 & 1 & 1 & & 13 \\
\hline Toxocara canis & & & & 1 & & & 1 & 2 \\
\hline Toxascaris leonina & & & & & & & 1 & 1 \\
\hline F. osleri & & & & & & & 1 & 1 \\
\hline $\begin{array}{l}\text { Nematodos } \\
\text { ancylostomatidos }\end{array}$ & 1 & & 2 & 2 & & & & 5 \\
\hline Trichuris sp. & & & & 2 & & & & 2 \\
\hline \multicolumn{9}{|l|}{ Cestoda } \\
\hline Taenia sp. & 1 & & & & & & & 1 \\
\hline Spirometra sp. & & 6 & 1 & 3 & & & & 10 \\
\hline \multicolumn{9}{|l|}{ Protozoa } \\
\hline Isospora sp. & 1 & & 1 & 2 & & & & 4 \\
\hline Total & 4 & 7 & 5 & 19 & 1 & 1 & 3 & 40 \\
\hline
\end{tabular}

well as on the age, health and the immunity acquired by the host. Species of Uncinaria infest small intestines of carnivores and are less pathogenic than the common canid hookworm Ancylostoma caninum (Browman 1999), which was not found in this survey. Species of Uncinaria have been reported in chillas from Magallanes (Alarcón 2005).

Two samples (1.1\%) that contained eggs of Trichuris sp. were from Quilán. This parasite might correspond to Trichuris vulpis (Froelich 1789), a species already recorded in domestic dogs in Chile (Tagle 1966). Two cestodes were identified: Spirometra sp. (5.3\%) and Taenia sp. (1.1\%). Taeniids generally cannot be identified to species based on eggs alone (Browman 1999). At least two species of Taenia have been reported from necropsies of foxes in Chile (Alarcón 2005, González-Acuña ${ }^{4}$ ). We found only one sample with eggs belonged to Taenia sp. The definitive hosts for species of Taenia are usually dogs (Tagle 1966) and foxes (Moro et al 1998, Zanini et al 2006). These findings demonstrate that foxes can be a sylvatic reservoir for these cestodes in this region. Four samples $(2.1 \%)$ were positive with the protozoan Isospora sp., a similar prevalence to that found by Gorman et al (1989) for Isospora sp. in domestic dogs. Isospora ohioensis (Dubey 1975), I. canis (Nemeseri 1959) and I. bahiensis (Stiles 1901) have been recorded from domestic dogs in Chile (Alcaino and Ábalos 1965, Gorman et al 1989).
It must be noted that the figures on parasite prevalence in the faeces may inflate the prevalence estimates of parasites in the fox populations, as we found more faeces per site as the number of known foxes per locality (see Materials and Methods).

The highest prevalence of endoparasites on a seasonal basis was observed during winter (47.4\%) and the lowest in summer (9.8\%, table 2). However, considering the small number of samples $(n=9)$, further studies are needed to confirm this result. Unexpectedly, we found that most faeces had no evidence of parasites or that most infected faeces had only one parasite taxa. This may be due to a constraint in the technique used.

Darwin's foxes are generalist feeders (Jiménez 1997) and, therefore, it is not surprising that many of the endoparasite genera that infest them also infest the abundant and non-managed domestic dogs. Furthermore, in several areas in Chiloé, foxes live intermixed with dogs and thus the contact rate and likelihood of parasite transmission can be very high. Our preliminary results on our research on dog health based upon dog medical examinations and questionnaires to their owners, also show that there is little, if not absent, sanitary care (e.g. deworming, immunizations, medical checks) provided by locals to their pets (Briceño et $a l^{5}$ ), and these may carry a high parasite load. A comparison of the prevalence and taxonomic composition of the endoparasites of domestic dogs as well as their modes

$4 \quad$ Personal communication.

5 Personal communication. 
Table 2. Seasonal prevalence of parasite eggs and oocysts in the feces of the Darwin's fox (Pseudalopex fulvipes) in Chiloé Island, southern Chile.

de Chile.

Prevalencia estacional de huevos y oocitos de parásitos en las heces de zorros de Darwin (Pseudalopex fulvipes) en la Isla de Chiloé, sur

\begin{tabular}{|c|c|c|c|c|c|}
\hline Endoparasites & $\begin{array}{c}\text { Summer } \\
\mathrm{n}=61\end{array}$ & $\begin{array}{c}\text { Autumn } \\
\mathrm{n}=54\end{array}$ & $\begin{array}{l}\text { Winter } \\
\mathrm{n}=19\end{array}$ & $\begin{array}{l}\text { Spring } \\
\mathrm{n}=55\end{array}$ & $\begin{array}{c}\text { Total } \\
\mathrm{n}=189\end{array}$ \\
\hline \multicolumn{6}{|l|}{ Nematoda } \\
\hline Capillaria sp. & & & & 1 & 1 \\
\hline Ascarido & 2 & 6 & 2 & 3 & 13 \\
\hline Toxocara canis & 1 & & & 1 & 2 \\
\hline Toxascaris leonina & 1 & & & & 1 \\
\hline Filaroides osleri & 1 & & & & 1 \\
\hline Ancylostomatid nematods & & 1 & 3 & 1 & 5 \\
\hline Trichuris sp. & & & 1 & 1 & 2 \\
\hline \multicolumn{6}{|l|}{ Cestoda } \\
\hline Taenia sp. & & 1 & & & 1 \\
\hline Spirometra sp. & & 3 & 1 & 6 & 10 \\
\hline \multicolumn{6}{|l|}{ Protozoa } \\
\hline Isospora sp. & 1 & 1 & 2 & & 4 \\
\hline Total & 6 & 12 & 9 & 13 & 40 \\
\hline
\end{tabular}

of transmission would be of interest to further understand the results obtained in this study.

As mentioned by Zajac (1994), the identification to species level of the endoparasites recorded will provide a greater insight into the overlap of parasite communities among sympatric carnivores, mainly with domestic dogs. Also, collecting more samples from different locations in Chiloé over longer periods of time and collecting samples from Darwin's fox at the mainland locality in Chile (Nahuelbuta), may improve our knowledge of the ecological and behavioral factors that increase the susceptibility of fox to the parasitic infections.

Data on parasite burdens are an important component of site-specific health assessment plans for fox populations. Stray dogs may affect Darwin's foxes through harmful interactions such as direct persecution and killing, competition for food, transmission of viral diseases (Jiménez and McMahon 2004), ectoparasites (González et al 2007), and endoparasites. Although this information is necessary to understand the impact of dog activities and management efforts on wildlife and human populations, as well as to develop responsible long-term conservation strategies, we do not know whether the parasites found in Darwin's foxes substantially affect their ecology and fitness. The effects of dogs on foxes have been documented in Chile and therefore it is expected that this also occurs with the Darwin's fox (Silva-Rodríguez et al 2010). However, the precautionary principle calls for a better control and health management of dogs in developed areas of Chiloé, and to exclude them altogether from conservation areas, such as
Tepuhueico and Ahuenco, to help the conservation of the critically endangered Darwin's fox.

\section{SUMMARY}

A total of 189 faecal samples of the critically endangered Darwin's fox (Pseudalopex fulvipes [Martin, 1837]), from different areas within Chiloé Island in southern Chile were examined for parasites eggs and oocysts using the sugar flotation technique. The results showed that $21.2 \%$ of the samples were positive to either one of nine helminthes and one protozoan. The parasites with the highest prevalence were an ascarid nematode and a Spirometra species of cestode. Other identified endoparasites include Capillaria sp., Toxocara canis, Toxascaris leonina, Filaroides osleri, ancylostomatid nematodes, Trichuris sp., Taenia sp., and Isospora sp. Parasite loads were higher during the winter and in areas having more domestic dogs. All these species and genera are reported for the fist time in the Darwin's fox.

\section{REFERENCES}

Aguilera J. 2001. Estudio preliminar de equinococosis y helmintiasis gastrointestinal en zorro gris (Pseudalopex griseus) silvestre de Tierra del Fuego, Chile. Memoria de Título, Escuela de Medicina Veterinaria, Universidad de Concepción, Chillán, Chile.

Alarcón U. 2005. Estudio taxonómico de la fauna parasitaria del tracto gastrointestinal de zorro gris (Pseudalopex griseus, Gray 1837), en la XII Región de Magallanes y Antártica Chilena. Memoria de Título, Escuela de Medicina Veterinaria, Universidad Austral de Chile, Valdivia, Chile.

Alcaíno H, P Abalos. 1965. Contribución al estudio de la isosporosis canina. Rev Soc Med Vet Chile 15, 1-4.

Alcaíno H, J Huerta. 1970. Uncinaria stenocephala (Nematoda: Ancylostomidae) en perros de Chile. Bol Chileno Parasitol 25, 136-137.

Alcaíno H, T Gorman. 1999. Parásitos de los animales domésticos en Chile. Parasitol al día 23, 33-41. 
Alvarez V. 1960. Presencia de Linguatula serrata Froelich, 1789, en Dusicyon culpaeus y de formas ninfales en $O$. d. degus y A. b. bennetti. Bol Chileno Parasitol 15, 22.

Armesto JJ, C Villagrán, MK Arroyo. 1996. Ecología de los bosques nativos de Chile. Editorial Universitaria, Santiago, Chile.

Boehmwald H, P Torres, G Hotta, H González. 1971. Primer hallazgo de Capillaria aerophila (Creplin, 1839) (Nematoda, Trichuroidea) en Chile. Arch Med Vet 3, 130-133.

Browman DD. 1999. Georgis' parasitology for veterinarians. $7^{\text {th }}$ ed. WB Saunders Company, Philadelphia, USA.

Bush A, K Lafferty, J Lotz, A Shostak. 1997. Parasitology meet ecology on its own terms: Margolis et al revisited. J Parasitol 83, 575-583.

Donoso R, O Skewes, L Rubilar, S Donoso, C Brevis. 2000. Estudio histopatológico de Sarcocystis sp. en el intestino delgado de zorro gris (Pseudalopex griseus) de Tierra del Fuego, Chile. XI Congreso Chileno de Medicina Veterinaria, Santiago, Chile.

González-Acuña D, C Briceño, A Cicchino, SM Funk, J Jiménez. 2007. First records of Tricodectes canis (Insecta: Phthiraptera: Trichodectidae) from Darwin's fox, Pseudalopex fulvipes (Mammalia: Carnivora: Canidae). Eur J Wildlife Res 53, 76-79.

Gorman T, V Yáñez, H Alcaíno. 1989. Coccidias intestinales en caninos de la comuna de San Miguel, Región Metropolitana. Avances Ciencias Vet 4, 57-62.

Jiménez J, E McMahon. 2004. Darwin's fox Pseudalopex fulvipes (Martin, 1837). In: Sillero-Zubiri C, Hoffmann M, Macdonald DW (eds). Canids: foxes, wolves, jackals and dogs. Status survey and conservation action plan. IUCN/SSC Canid Specialist Group. Gland, Switzerland and Cambridge, UK, Pp 50-55.

Jiménez JE. 2007. Ecology of a coastal population of the critically endangered Darwin's fox (Pseudalopex fulvipes) on Chiloé Island, southern Chile. J Zool 271, 63-77.

Killian K, 2005. Telemetrische Untersuchung zum Einfluss des Menschen auf die Lebensraumnutzung des Darwin-Fuchses (Pseudalopex fulvipes, Martin 1837) auf Chiloé, Chile. Biology thesis, Hamburg University, Germany.

Luengo M, N Arata. 1970. Filarioides osleri como hallazgo de necropsia en canino. Bol Chil Parasitol 25, 87-88.

Macdonald DW, C Sillero-Zubiri. 2004. Biology and conservation of wild canids. Oxford University Press, Oxford, UK.

Martínez-Fernández AR, A Muro-Alvarez, F Simón-Martín. 1999. Diagnóstico de la parasitosis. In: Cordero del Campillo M, Rojo FA (eds). Parasitología veterinaria. M McGraw-Hill, Interamericana, Madrid, España, Pp 158-177.

Moro PL, J Ballarta, RH Gilman, G Legia, M Rojas, G Montes. 1998. Intestinal parasites of the grey fox (Pseudalopex culpaeus) in the central Peruvian Andes. J Helminthol 72, 87-89.

Silva-Rodríguez EA, GR Ortega-Solís, JE Jiménez. 2010. Conservation and ecological implications of the use of space by chilla foxes and free-ranging dogs in a human-dominated landscape in southern Chile. Austral Ecology 35, 765-767.

Tagle I. 1966. Parásitos de los animales domésticos en Chile. Bol Chil Parasitol 21, 118-121.

Torres P. 1971. Hallazgo de Capillaria plica (Rudolphi, 1819) (Nematoda: Trichuroidea) en Chile. Arch Med Vet 3, 47-49.

Torres P, M Ramos, L Carrasco, M Neumann, R Franjola, N Navarrete, L Figueroa. 1974. Protozoos, helmintos y artrópodos parásitos del perro doméstico en la ciudad de Valdivia, Chile. Bol Chil Parasitol 29, 18-23.

Zajac AM. 1994. Faecal examination in the diagnosis of parasitism. In: Sloss MW, Kemp RK, Zajac AM (eds). Veterinary clinical parasitology. $6^{\text {th }}$ ed. Iowa State University Press, Ames, Iowa, USA, Pp 3-88.

Zanini F, M Laferrara, M Bitsch, H Pérez, MC Elissondo. 2006. Epidemiological studies on intestinal helminth parasites of the Patagonian grey fox (Pseudalopex griseus) in Tierra del Fuego, Patagonia, Argentina. Vet Parasitol 136, 329-334. 